\title{
PENGARUH ANTOSIANIN UBI UNGU (Ipomoea batatas L.) KULTIVAR GUNUNG KAWI TERHADAP EKSPRESI CASPASE-3 PADA JARINGAN OTAK TIKUS MODEL DM TIPE 2
}

\author{
Ardani Galih Prakosa ${ }^{\star \varpi}$, Retty Ratnawati, Risma Karlina Prabawati ${ }^{* *}$
}

\begin{abstract}
Abstrak
Diabetes melitus (DM) merupakangangguan metabolism yang menyebabkan kondisi hiperglikemia. Hiperglikemia akan memicu pembentukan radikal bebas. Radikal bebas yang berlebihan dapat merusak sistem membran sel dan kematian sel di berbagai jaringan tubuh. Salah satu penanda terjadinya kematian sel pada suatu jaringan adalah caspase-3. Ubi ungu merupakan tanaman tradisional yang mengandung antosianin yang bermanfaat sebagai antiinflamasi, antioksidan, neuroprotektan, dan antidiabetik. Penelitian ini dilakukan untuk mengetahui pengaruh pemberian antosianin ubi ungu terhadap ekspresi caspase-3 pada jaringan otak tikus Wistar yang diinduksi DM tipe 2. Penelitian ini menggunakan desain eksperimental post-test only control group. Sampel penelitian terbagi menjadi 5 kelompok yaitu kontrol negatif, kontrol positif, antosianin dosis $10 \mathrm{mg} / \mathrm{kgBB}$, dosis $20 \mathrm{mg} / \mathrm{kgBB}$, dan dosis $80 \mathrm{mg} / \mathrm{kgBB}$ selama 5 minggu. Kontrol positif adalah tikus yang dibuat DM tipe 2, sedangkan kontrol negatif adalah tikus sehat. Ekspresi caspase3 diukur dengan metode imunohistokimia. Analisis statistik menunjukkan bahwa ekspresi caspase-3 berbeda secara bermakna pada semua kelompok perlakuan (ANOVA, $p<0,05$ ). Pemberian antosianin dosis 10 dan $20 \mathrm{mg} / \mathrm{kgBB}$ menurunkan ekspresi caspase-3 secara bermakna dibandingkan kontrol positif, sedangkan pemberian antosianindosis $80 \mathrm{mg} / \mathrm{kgBB}$ justru meningkatkan ekspresi caspase-3. Dapat disimpulkan bahwa pemberian antosianin dosis 10 dan $20 \mathrm{mg} / \mathrm{kgBB}$ menurunkan ekspresi caspase-3 pada jaringan otak tikus wistar model DM tipe 2.
\end{abstract}

Kata kunci: antosianin, ekspresi caspase-3, hiperglikemia, jaringan otak

\section{THE EFFECT OF PURPLE SWEET POTATO (Ipomoea batatas L.) ANTHOCYANIN ON THE EXPRESSION OF CASPASE-3 IN BRAIN TISSUE OF DIABETES MELLITUS TYPE 2- INDUCED RATS}

\begin{abstract}
Diabetes mellitus (DM) is a metabolic disorder that leads to the condition of hyperglycemia. Hyperglycemia will trigger the formation of free radicals. Excessive free radicals can damage the cell membrane system and cell death in various tissues. Caspase-3 is a marker of cell death in a tissue. Purple sweet potato is a traditional crop that contain anthocyanins that are useful as antiinflammatory, antioxidant, neuroprotectant, and antidiabetic. This study was conducted to determine the effect of purple sweet potato anthocyanin on the expression of caspase-3 in brain tissue of diabetes mellitus type 2-induced Wistar rats. This study used an experimental post-test only control group design. The research sample was divided into 5 groups: negative control, positive control, anthocyanin dose of $10 \mathrm{mg} / \mathrm{kg}$, dose of $20 \mathrm{mg} / \mathrm{kg}$, and dose of $80 \mathrm{mg} / \mathrm{kg}$ for 6 weeks. Positive control contained of rats with DM type 2, whereas negative control contained of the healthy rats. The expression of caspase-3 was measured by immunohistochemistry methods. Statistic analysis result showed that the expression of caspase-3 increased significantly in all treatment groups (ANOVA, $p<0,05$ ). Anthocyanin dose of 10 and $20 \mathrm{mg} / \mathrm{kg}$ treatment decreased the expression of caspase-3 significantly more than the positive control. While the treatment of anthocyanin dose of $80 \mathrm{mg} / \mathrm{kg}$ body weight actually increase the expression of caspase-3. It can be concluded that the administration of anthocyanin doses 10 and $20 \mathrm{mg} / \mathrm{kg}$ decreased the expression of caspase-3 in brain tissue Wistar rat model of type 2 diabetes.
\end{abstract}

Keywords: anthocyanin, brain tissue, caspase-3 expression, hyperglycemia

\footnotetext{
* Lab Fisiologi, FK UB

${ }^{*}$ Program Studi Pendidikan Dokter Spesialis Neurologi, FK UB-RSSA
}

\footnotetext{
E-mail: ardanigalih@gmail.com
} 


\section{Pendahuluan}

Diabetes melitus (DM) tipe 2 merupakan gangguan metabolisme yang ditandai dengan gangguan sekresi insulin, resistensi insulin, produksi glukosa hepatik berlebihan, dan gangguan metabolisme lemak, yang pada akhirnya akan menimbulkan kondisi hiperglikemia. ${ }^{1}$

Jumlah penderita DM selama tiga dekade terakhir telah mencapai lebih dari dua kali lipat secara global, menjadikan salah satu tantangan kesehatan masyarakat yang paling penting untuk semua bangsa. DM tipe 2 dan prediabetes semakin banyak terjadi pada anak-anak, remaja, dan dewasa muda. Penyebab diabetes melitus tipe 2 sangat kompleks mulai dari sistem genetik yang berinteraksi dengan perilaku dan pengaruh lingkungan. ${ }^{2}$ Menurut data RISKESDAS 2013, prevalensi DM di Indonesia berdasarkan yang terdiagnosis dokter atau gejala sebesar 2,1\%, untuk Jawa Timur sendiri menempati peringkat 4 sebesar $2,1 \%{ }^{3}$

Gangguan metabolisme yang terjadi pada tubuh penderita DM menyebabkan perubahan fungsional dan struktural dalam sistem saraf pusat. Atrofi serebral moderat dan peningkatan lesi subkortikal dan batang otak telah dilaporkan pada pasien diabetes yang tidak terkontrol. Penelitian sebelumnya telah menyatakan bahwa memori, belajar, dan gangguan kognitif lebih umum pada penderita diabetes dibandingkan pasien non diabetes. $^{4}$

Hiperglikemia pada DM menyebabkan kenaikan kadar radikal bebas. Proses autooksidasi pada hiperglikemi memicu pembentukan radikal bebas. Radikal bebas dapat merusak membran sel, menjadi lipid peroksida atau malondialdehyde (MDA), bila berlanjut mengakibatkan kerusakan sistem membran sel dan kematian sel. ${ }^{4}$ Penelitian lain menunjukkan diabetes melitus mengurangi fungsi belajar dan memori tikus, merusak struktur neuron hipokampus dan sinapsis, dan menginduksi apoptosis neuronal yang ditunjukkan dengan meningkatnya aktivitas caspase- $3 .{ }^{5}$ Caspase adalah keluarga sisteinil protease spesifik aspartat yang terdapat pada organisme multiselular dan berfungsi sebagai regulator sentral apoptosis. Salah satu anggotanya, caspase-3, telah diidentifikasi sebagai mediator apoptosis dalam sel neuron. ${ }^{6}$ Antosianin termasuk dalam kelompok flavonoid, yang memiliki kelompok fenolik pada struktur kimiawinya dan memberikan warna pada beberapa bunga dan buah. ${ }^{7}$ Antosianin juga memiliki peran sebagai antiinflamasi dan neuroprotektan. ${ }^{8}$

Studi untuk meneliti efek antioksidan dan antiinflamasi antosianin pada tikus model Alzheimer menunjukkan bahwa antosianin memberikan efek positif pada fungsi kognitif tikus model tersebut. ${ }^{9}$ Namun, belum banyak penelitian yang mengamati efek antosianin terhadap kematian sel otak tikus model diabetes. Berdasarkan hal tersebut maka dilakukan penelitian untuk mengetahui pengaruh pemberian antosianin terhadap ekspresi caspase-3 sebagai penanda kematian sel pada jaringan otak tikus model DM tipe 2.

\section{Bahan dan Metode}

Desain Penelitian:

Penelitian ini menggunakan desain eksperimental laboratorik, post-test only control group dengan menggunakan tikus Wistar yang diinduksi DM tipe 2. Perlakuan dibagi menjadi 5 kelompok, yaitu: kelompok kontrol negatif yaitu tikus Wistar yang tidak diberi diet tinggi lemak maupun injeksi streptozotocin, kelompok kontrol positif yaitu tikus Wistar yang diberi diet tinggi lemak dan injeksi streptozotocin tanpa antosianin, kelompok P1 yaitu tikus Wistar yang diberi diet tinggi lemak dan injeksi streptozotocin dan diberi ekstrak antosianin $10 \mathrm{mg} / \mathrm{kgBB}$, kelompok P2 yaitu tikus Wistar yang diberi diet tinggi lemak dan injeksi streptozotocin dan diberi ekstrak antosianin $20 \mathrm{mg} / \mathrm{kgBB}$, dan kelompok P3 yaitu tikus Wistar yang 
diberi diet tinggi lemak dan injeksi streptozotocin dan diberi ekstrak antosianin $80 \mathrm{mg} / \mathrm{kgBB}$. Penelitian dilakukan di Laboratorium Farmakologi, Laboratorium Patologi Anatomi dan Laboratorium Fisiologi, Fakultas Kedokteran Universitas Brawijaya Malang. Sampel penelitian adalah tikus Wistar jantan, berat 125-175 gram, umur 6-8 minggu, berasal dari Eijkman Institute Jakarta. Penelitian telah disetujui oleh Komisi Etik Fakultas Kedokteran Universitas Brawijaya Malang.

Induksi Diabetes:

Tikus Wistar diberi diet tinggi lemak selama 6 minggu dan injeksi streptozotocin intraperitonial dengan dosis $35 \mathrm{mg} / \mathrm{kg}$ pada akhir minggu keenam dan $35 \mathrm{mg} / \mathrm{kg} 24$ jam setelah injeksi pertama, jika belum terjadi hiperglikemia. Diet tinggi lemak terdiridari PARS 50\%, tepung terigu $25 \%$, kolesterol $1 \%$, asam cholat $0,1 \%$, minyak babi $2,5 \%$, dan air $21,4 \%$. Diet tinggi lemak diberikan pada minggu ke-1 hingga ke-6.

Pemberian Antosianin Ubi Ungu:

Antosianin yang digunakan pada penelitian ini telah melalui proses purifikasi yaitu berasal dari ubi jalar ungu kultivar Gunung Kawi yang dilakukan oleh Dr. Ciptati, MS., di Laboratorium Kimia FMIPA ITB Bandung dengan menggunakan kromatografi kolom flash termodifikasi dengan fasa diam poliamida C- 6 dan fasa gerak air dan etanol. Pemberian ekstrak antosianin diberikan secara per oral satu kali setiap hari selama 5 minggu dengan dosis 10, 20 dan $80 \mathrm{mg} / \mathrm{kgBB} .{ }^{11}$

\section{Preparasi Sampel Otak:}

Pembedahan dilakukan pada minggu ke-7 setelah pemberian diet tinggi lemak. Tikus dimatikan dengan pemberian eter perinhalasi. Setelah tikus dipastikan tidak sadar (tidak menunjukkan gerakan spontan), dilakukan pembedahan untuk mengambil jaringan otak tikus. Pembedahan tersebut dilakukan dengan cara menggunting kranium dengan arah sagital dari kaudal (oksipital) menuju ke rostral (frontal), tepat di antara kedua hemisfer otak tikus. Selanjutnya dilakukan pembebasan otak tikus pada regio basal dari jaringan ikat sekitarnya. Botol yang berisi jaringan otak dan larutan formalin tersebut ditutup rapat. Selanjutnya dilakukan pengirisan jaringan otak dan pembuatan slide dengan paraffin block.

Pembuatan Preparat Jaringan Otak: Jaringan otak dimasukkan tabung formalin $10 \%$ dipotong dengan rotary microtom setebal 4 mikron dan diletakkan dalam poly-L-lysine object glass dan dibiarkan dalam suhu kamar. Selanjutnya dilakukan deparafinisasi, tetapi sebelumnya slide dipanaskan dahulu pada suhu $60^{\circ} \mathrm{C}$ selama 60 menit. Kemudian ditambahkan dengan larutan berikut ini secara berurutan yaitu: xylol (2x10 menit), etanol absolut (2x10 menit), etanol 90\% (1x5 menit), etanol $80 \%$ ( $1 \times 5$ menit), etanol $70 \%$ ( $1 \times 5$ menit), aquades steril ( $3 \times 5$ menit).

Pengukuran Caspase-3 dengan Metode Imunohistokimia:

Langkah awal adalah proses antigen retrieval dengan buffer sitrat. Slide direndam dalam chamber berisi buffer sitrat $\mathrm{pH} 6,0$, kemudian dipanaskan dalam waterbath suhu $95^{\circ} \mathrm{C}$ selama 20 menit. Slide dikeluarkan dari waterbath, ditunggu sampai suhu ruang ( \pm 20 menit) kemudian dicuci dengan PBS (3×2 menit). Selanjutnya dilakukan proses pengecatan secara immunohistokimia sebagai berikut: slide ditetesi dengan $3 \%$ $\mathrm{H}_{2} \mathrm{O}_{2}$ dalam metanol dan diinkubasi selama 15 menit, kemudian dicuci dengan PBS selama 2 menit sebanyak 3 kali. Setelah itu, dilakukan blocking unspecific protein dengan diteteskan background sniper, diinkubasi 15 menit pada suhu ruang, kemudian dicuci dengan PBS selama 2 menit sebanyak 3 kali. Diteteskan antibodi primer (anticaspase-3 yang dilarutkan dalam buffer PBS dengan perbandingan 1:50 dan $5 \%$ 
FBS) selama semalam pada suhu $4^{\circ} \mathrm{C}$. Slide kemudian diinkubasi dengan antibodi sekunder 30 menit pada suhu ruang kemudian dicuci dengan PBS selama 2 menit sebanyak 3 kali. Setelah itu, diinkubasi enzim SA-HRP selama 20 menit pada suhu ruang, kemudian dicuci dengan PBS selama 2 menit sebanyak 3 kali dan dibilas dengan aquades. Diteteskan DAB dan DAB buffer dengan perbandingan 1:50 dan diinkubasi 310 menit pada suhu ruang, kemudian dicuci dengan PBS selama 2 menit sebanyak 3 kali dan dicuci dengan aquadest selama 2 menit sebanyak 3 kali. Selanjutnya diteteskan Mayer dan tap water dengan perbandingan 1:10 dan diinkubasi 5-10 menit pada suhu ruang, kemudian dibilas dengan tap water, dikeringkan dan diamati di bawah mikroskop dengan perbesaran 400 kali.

Analisis Statistik:

Data yang diperoleh dalam penelitian dianalisissecara statistik dengan uji oneway
ANOVA untuk mengetahui adanya perbedaan ekspresi caspase-3, pada kelompok perlakuan. Hasil uji statistik bernilai signifikan jika $p<0,05$. Kemudian, dilanjutkan uji Tukey untuk mencari letak perbedaan yang signifikan pada kelompok perlakuan. Uji korelasi Pearson digunakan untuk mengetahui korelasi antara dosis antosianin dengan ekspresi caspase-3.

\section{Hasil}

\section{Ekspresi Caspase-3:}

Ekspresi caspase-3 diamati dan diukur melalui pemeriksaan imunohistokimia pada sampel otak tikus menggunakan mikroskop pada perbesaran 400x. Sel yang mengekspresikan caspase-3 menunjukkan sitoplasma yang berwarna berwarna coklat pada semua jenis sel. Pengukuran dilakukan dengan cara menghitung rerata sel yang mengekspresikan caspase-3 dari 10 lapang pandang (Gambar 1).
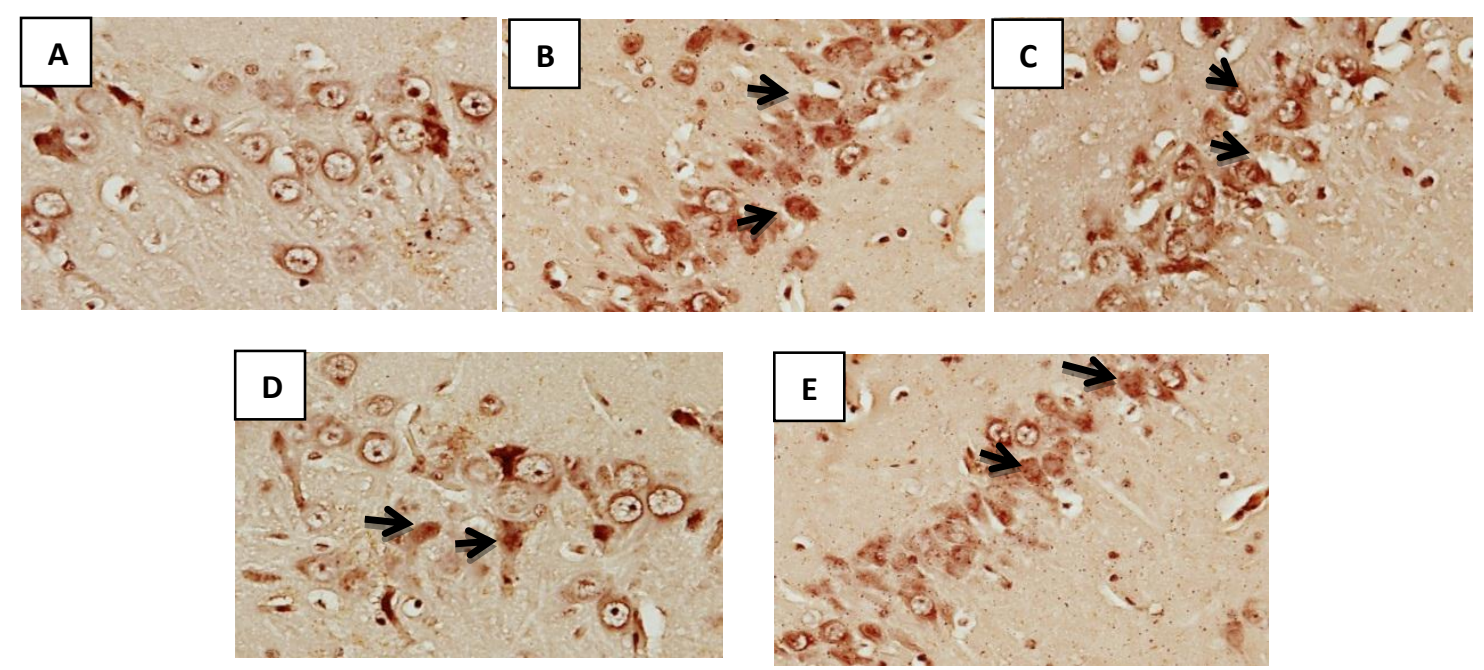

Gambar 1. Ekspresi caspase-3 otak tikus pada hari ke-50 dengan metode imunohistokimia (perbesaran 400x). Sel yang mengekspresikan caspase-3 tampak berwarna kecoklatan (tanda panah). Keterangan: A. Ekspresi caspase-3 pada kelompok kontrol negatif; B. Ekspresi caspase-3 pada kelompok kontrol positif; C. Ekspresi caspase-3 pada kelompok P1; D. Ekspresi caspase-3 pada kelompok P2; E. Ekspresi caspase-3 pada kelompok P3.

Grafik rata-rata ekspresi caspase-3 pada otak tikus Wistar pada tiap-tiap kelompok di hari ke-50 dapat dilihat pada Gambar 2. Analisis perbandingan ekspresi caspase-3 menunjukkan adanya perbedaan yang signifikan pada kelima kelompok $(p<$ $0,05)$. Ekspresi caspase-3 pada kelompok kontrol negatif berbeda signifikan dengan kelompok kontrol positif, P1, P2, dan P3. Ekspresi caspase-3 pada kelompok kontrol 
positif berbeda signifikan dengan kelompok kontrol negatif, P1, P2, dan P3. Ekspresi caspase-3 pada kelompok P3 berbeda signifikan dengan kelompok kontrol negatif, kelompok kontrol positif, P1 dan P2. Ekspresi caspase-3 tertinggi pada kelompok kontrol positif dan terendah pada kelompok kontrol negatif.

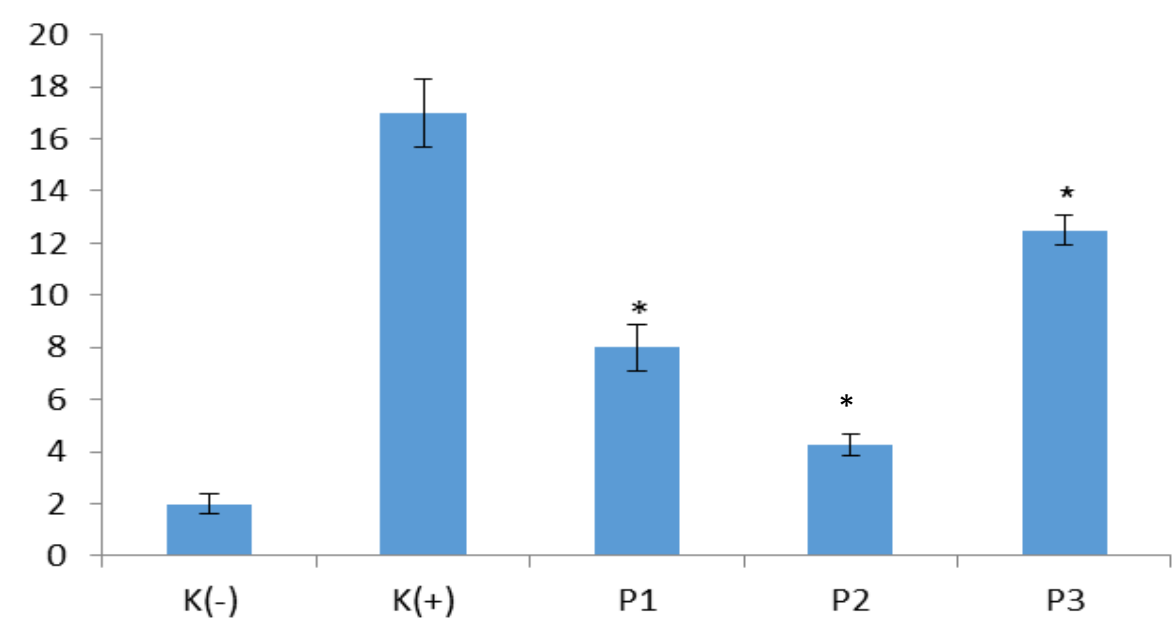

Gambar 2. Rerata ekspresi caspase-3 otak tikus Wistar antar perlakuan.Keterangan: K(-): kontrol negatif; $\mathrm{K}(+)$ : kontrol positif; $\mathrm{P} 1$ : antosianin dosis $10 \mathrm{mg} / \mathrm{kgBB}$; $\mathrm{P} 2$ : antosianin dosis 20 $\mathrm{mg} / \mathrm{kgBB}$; P3: antosianin dosis $80 \mathrm{mg} / \mathrm{kgBB}$.

Berdasarkan hasil uji korelasi menunjukkan nilai koefisien korelasi antara ekspresi caspase-3 pada otak tikus Wistar dan dosis ekstrak antosianin sebesar 0,207 dengan nilai signifikansi sebesar $0,381(p>0,05)$, sehingga dapat disimpulkan bahwa tidak terdapat hubungan yang signifikan antara ekspresi caspase-3 pada otak tikus Wistar dan dosis ekstrak antosianin.

\section{Pembahasan}

Pada penelitian ini didapatkan adanya peningkatan ekspresi caspase-3 pada kelompok tikus yang diinduksi DM tipe 2 . Hasil ini sesuai dengan penelitian sebelumnya yang menunjukkan peningkatan ekspresi caspase-3 pada hipokampus tikus yang diinduksi streptozotocin dibanding dengan tikus yang tidak dinduksi diabetes dengan menggunakan streptozotocin. ${ }^{10}$

Enzim caspase-3 merupakan efektor proses apoptosis yang memegang peranan penting dalam proses degradasi sel. Hiperglikemia yang terjadi pada pasien diabetes mellitus dihubungkan dengan proses stres oksidatif yang akan memicu kematian sel neuron dansel Schwann melalui peningkatan aktivitas caspase-3.10

Berdasarkan data penelitian di atas diketahui bahwa terjadi penurunan ekspresi caspase-3 yang signifikan pada kelompok perlakuan dosis $10 \mathrm{mg} / \mathrm{kgBB}$ dan 20 $\mathrm{mg} / \mathrm{kgBB}$ dibandingkan dengan kelompok perlakuan kontrol positif dan perlakuan dosis $80 \mathrm{mg} / \mathrm{kgBB}$. Hal ini berarti pemberian antosianin pada dosis $10 \mathrm{mg} / \mathrm{kgBB}$ dan 20 $\mathrm{mg} / \mathrm{kgBB}$ dapat menghambat peningkatan ekspresi caspase-3, namun pada dosis 80 $\mathrm{mg} / \mathrm{kgBB}$ justru meningkatkan ekspresi caspase-3.

Hasil penelitian ini sesuai dengan hasil penelitian lain, bahwa antosianin sebagai antioksidan akan melindungi sel endotel terhadap stress oksidatif dengan menghambat apoptosis sel melalui proteksi membran mitokondria dan down regulation aktivasi caspase-3. ${ }^{11}$ Pada penelitian lain yang dilakukan pada retina, antosianin terbukti menghambat degenerasi retina 
melalui peningkatan produksi enzim antioksidan, penurunan jumlah peroksidasi lipid (MDA), dan hambatan apoptosis yang ditunjukkan dengan penurunan ekspresi caspase-3. ${ }^{12}$

Antosianin dapat mencapai otak yang normal melalui mekanisme yang masih belum dapat dijelaskan dengan baik. Sebelum masuk ke otak, antosianin sebagai salah satu jenis flavonoid, harus melewati sawar darah otak terlebih dahulu (blood brain barrier). Derajat penetrasi golongan flavonoid ini bergantung pada tingkat lipofilisitas (senyawa yang tidak polar lebih besar penetrasinya dibanding senyawa yang polar (terglukoronidasi)). Antosianin sebagai salah satu senyawa yang mengalami proses glukoronidasi kemungkinan masuk ke otak melalui mekanisme yang lain (selain difusi langsung). Antosianin diduga masuk melalui transporter spesifik yang diekspresikan di endotel sawar darah otak, yaitu Pglycoprotein. Antosianin juga ditemukan lebih banyak terdapat pada daerah hipokampus dan korteks serebri. ${ }^{10}$

Lebih lanjut, hasil penelitian ini menunjukkan bahwa pemberian antosianin dosis $80 \mathrm{mg} / \mathrm{kgBB}$ meningkatkan ekspresi caspase-3 otak tikus dan mendekati kontrol positif. Hasil pada penelitian lain pada sel kanker kolon, antosianin justru memicu terjadinya stress oksidatif dan memicu apoptosis sel kanker melalui aktivasi caspase- 3 pada dosis tertentu. ${ }^{13}$ Hal ini menunjukkan bahwa pada dosis tertentu, antosianin memiliki efek pro-oksidan dan pro-apoptosis, yang sesuai dengan hasil pada penelitian ini.

Teori yang dikemukakan oleh Gordon et al. menjelaskan bahwa besar konsentrasi antioksidan yang ditambahkan dapat berpengaruh pada laju oksidasi. ${ }^{14}$ Pada konsentrasi tinggi, aktivitas antioksidan kelompok fenolik sering lenyap bahkan antioksidan tersebut menjadi pro-oksidan. Pengaruh jumlah konsentrasi pada laju oksidasi tergantung pada struktur antioksidan, kondisi dan sampel yang akan diuji. Hal ini yang kemungkinan menyebabkan pada dosis tertentu maka efek antioksidan akan hilang pada suatu senyawaherbal. ${ }^{14}$ Teori ini dapat menjelaskan mengapa pada dosis $80 \mathrm{mg} / \mathrm{kgBB}$, pemberian antosianin malah meningkatkan jumlah caspase-3.

Dari uraian di atas dapat disimpulkan bahwa pemberian ekstrak antosianin ubi jalar ungu dosis $10 \mathrm{mg} / \mathrm{kgBB}$ dan $20 \mathrm{mg} / \mathrm{kgBB}$ dapat menurunkan ekspresi caspase-3 pada jaringan otak tikus Wistar yang diinduksi DM tipe2. Keterbatasan studi ini adalah dosis antosianin yang digunakan terlampau jauh jarak antar dosisnya, sehingga seolah-olah kenaikan dosis tidak memberikan efek penghambatan. Maka, diperlukan penelitian lanjutan yang menggunakan dosis antosianin di antara dosis 20 dan $80 \mathrm{mg} / \mathrm{kgBB}$. Juga seharusnya dilihat efek pemberian antosianin dengan dosis yang lebih besar dari $80 \mathrm{mg} / \mathrm{kgBB}$, sehingga dapat diketahui dengan pasti bahwa efek pro-oksidan dan pro-apoptosis ini hanya terjadi pada dosis tersebut atau memang terjadi toksisitas yang sifatnya subkronis. Dosis yang efektif belum dapat ditentukan pada penelitian ini, dikarenakan dosis yang terbukti berbeda bermakna hanya dua dosis, sedangkan untuk uji efektifitas dosis suatu bahan dibutuhkan setidaknya 11 tingkatan dosis. Pada penelitian ini juga tidak dilakukan pemeriksaan kadar $\mathrm{HbA} 1 \mathrm{c}$ dan kadar insulin sebagai konfirmasi yang menunjukkan terjadinya kerusakan pankreas,dan pemeriksaan perbaikan kadar glukosa darah.

\section{Daftar Pustaka}

1. Jameson LJ, Kasper LD, Longo DL et al. Harrison's Principles of Internal Medicine. $18^{\text {th }}$ Edition. US: The McGraw-Hill Companies Inc. 2012.

2. Chen L, Magliano DJ, Zimmet ZP. The Worldwide Epidemiology of Type 2 Diabetes Mellitus-Present and Future 
Perspectives. Nature Reviews Endocrinology. 2012; (8):228-236.

3. RISKESDAS. Badan Penelitian dan Pengembangan Kesehatan. Kementerian Kesehatan Republik Indonesia. Jakarta. 2013.

4. YongucNG,Dodurga Y,Adiguzel E, Gundogdu G,Kucukatay $V$ et al. Grape Seed Extract has Superior Beneficial Effects than Vitamin $E$ on Oxidative Stress and Apoptosis in the Hippocampus of Streptozotocin Induced Diabetic Rats. Gene. 2014; 555(2015): 119-126.

5. Zhang $Y, X u L, H e ~ D$, and Ling $S$. Endoplasmic Stress-Mediated Hippocampal Neuron Apoptosis Involved in Diabetic Cognitive Impairment. BioMed Research International. (Online) . 2013.https://www.hindawi.com/journals/b mri/2013/924327/.

6. D'Amelio M, Cavallucci V, Middei S, Marchetti C, Pacioni S, Ferri A, Diamantini $A$, De Zio $D$, Carrara $P$, Battistini L, Moreno $S$, Bacci A, Ammassari-Teule M, Marie H, Cecconi F. Caspase-3 Triggers Early Synaptic Dysfunction in a Mouse Model of Alzheimer's Disease. Nat Neurosci. 2011; 14(1):69-76. doi: 10.1038/nn.2709.

7. Yoshida K, Mori M,Kondo T. Blue Flower Color Development by Anthocyanins: from Chemical Structure to Cell Physiology. Nat Prod Rep. 2009; 26(7):884-915.

8. Min B, McClung AM, Chen MH. Phytochemicals and Antioxidant Capacities in Rice Brans of Different Color. J Food Sci. 2011; 76(1):C117-26.
9. Jessie M, Gutierres FB, Carvalho MRC, Schetinger PM. Anthocyanins Restore Behavioral and Biochemical Changes Caused by Streptozotocin-Induced Sporadic Dementia of Alzheimer's Type. Life Sciences. 2013; S00243205(13)00713-3.

10. VauzourD. Dietary Polyphenols as Modulators of Brain Functions: Biological Actions and Molecular Mechanisms Underpinning Their Beneficial Effects. Hindawi Publishing Corporattion. 2012.

11. Speciale $A$ et al. Bioavailability and Molecular Activities of Anthocyanins as Modulators of Endothelial Function. Genes Nutr. 2014; 9:404.

12. Wang $Y$ et al. Retinoprotective Effects of Bilberry Anthocyanins via Antioxidant, Antiinflammatory, and Anti-Apoptotic Mechanism in a Visible LightInduced Retinal Degeneration Model in Pigmented Rabbits. Journal Molecules. 2015; 20:22395-22410.

13. Anwar $S$ et al. Berry Anthocyanins Reduce Proliferation of Human Colorectal Carcinoma Cells by Inducing Caspase-3 Activation and P21 Upregulation. Mol Med Rep. 2016; 14(2):1397-1403.

14. Gordon MH. Food Antioxidants. In: The Mechanism of Antioxidant Action In Vitro. Elsevier. 1990. P 1-18. 